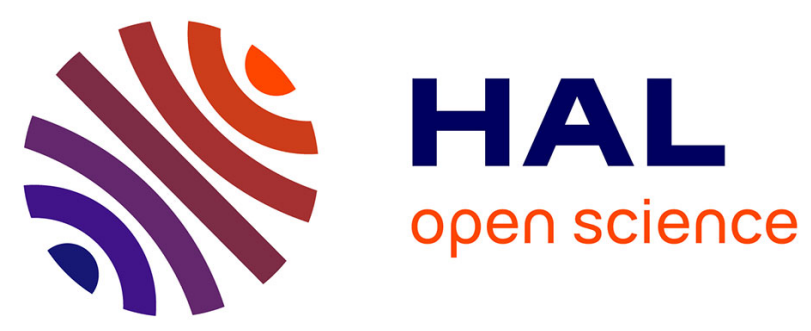

\title{
Growth anomalies in Pecten maximus from coastal waters (Bay of Brest, France): Relationship with diatom blooms
}

\author{
Anne Lorrain, Yves-Marie Paulet, Laurent Chauvaud, Nicolas Savoye, \\ Elisabeth Nézan, Laurent Guérin
}

\section{To cite this version:}

Anne Lorrain, Yves-Marie Paulet, Laurent Chauvaud, Nicolas Savoye, Elisabeth Nézan, et al.. Growth anomalies in Pecten maximus from coastal waters (Bay of Brest, France): Relationship with diatom blooms. Journal of the Marine Biological Association of the UK, 2000, 80 (4), pp.667-675. 10.1017/S0025315400002496 . hal-00452473

\section{HAL Id: hal-00452473 \\ https://hal.science/hal-00452473}

Submitted on 2 Feb 2010

HAL is a multi-disciplinary open access archive for the deposit and dissemination of scientific research documents, whether they are published or not. The documents may come from teaching and research institutions in France or abroad, or from public or private research centers.
L'archive ouverte pluridisciplinaire HAL, est destinée au dépôt et à la diffusion de documents scientifiques de niveau recherche, publiés ou non, émanant des établissements d'enseignement et de recherche français ou étrangers, des laboratoires publics ou privés. 


\title{
Growth anomalies in Pecten maximus from coastal waters
}

\section{(Bay of Brest, France): relationship with diatom blooms}

\author{
Anne Lorrain $^{1 *}$, Yves-Marie Paulet ${ }^{1}$, Laurent Chauvaud ${ }^{1}$, Nicolas Savoye ${ }^{1}$, \\ Elisabeth Nézan ${ }^{2}$ and Laurent Guérin ${ }^{3}$
}

(1) IUEM-UBO, UMR CNRS 6539, Technopôle Brest-Iroise, Place Copernic, 29280 Plouzané, France.

(2) IFREMER-Concarneau, 13, rue de Kérose, 29900 Concarneau, France.

(3) IUEM-UBO, UMR CNRS 6554, Technopôle Brest-Iroise, Place Copernic, 29280 Plouzané, France.

* Correspondant's name and adress:

Anne Lorrain

IUEM-UBO, UMR CNRS 6539, Technopôle Brest-Iroise, Place Copernic, 29280 Plouzané, France. Anne.Lorrain@univ-brest.fr

Key Words:

Daily shell growth, environmental factors, mass diatom sinking, nutrient limitation, Pecten maximus juveniles 


\begin{abstract}
Previous studies carried out with Pecten maximus (Bivalvia: Pectinidae) juveniles in the Bay of Brest have demonstrated that diatom and, more obviously, toxic dinoflagellate blooms could have a negative effect on the daily growth rate. The aim of this study was to characterize the daily shell growth from early 1998 to late spring 1999 with a careful qualitative and quantitative description of the pelagic primary production. Our results, in accordance with previous studies, demonstrate that there are episodic declines in the growth rate. Concurrent events of low growth rate and large bottom-concentrations of algae following diatom blooms (Cerataulina pelagica or Rhizosolenia delicatula), suggests that this high concentration of phytoplankton on the bottom layer, may affect food intake or respiratory activity of the scallops by gill clogging or oxygen depletion. In this study, silicic acid or phosphorus are inferred to be limiting factors responsible for the collapse of the spring bloom. Further, we suggest that, in an N-enriched ecosystem, Si or P-limitation and the changing sinking velocities of phytoplankton, could affect the biology of benthic suspension-feeders.
\end{abstract}

\title{
INTRODUCTION
}

External growth lines provide basic tools for studying environmental parameters recorded in the bivalve shell (for a review see Lutz \& Rhoads, 1980). In Pecten maximus juveniles, daily growth lines are visible and reflect the growth history of the animal at a dailyscale. Their shell contains information that allows us to reconstruct past and present-day environments. Immature juveniles are especially appropriate for such studies because of their rapid growth rate and because energy is not allocated from somatic growth to reproduction.

The environmental factors generally considered most important for bivalve growth are food availability and temperature (Broom \& Mason, 1978; MacDonald \& Thomson, 1985). 
However, growth in Pecten maximus of the Bay of Brest does not completely follow this paradigm (Chauvaud et al.,1998). Indeed food availability measured in the Bay of Brest is not limiting to scallop growth. The studies of Chauvaud et al., (1998) have related growth cessation to the massive sedimentation of diatom blooms or to toxic dinoflagellate blooms. These authors suggested that in 1995 the large aggregates of one species of diatom, Rhizosolenia delicatula, could have led to a reduction in feeding due to gill clogging, which in turn led to a cessation in growth.

The present study focused on both phytoplankton dynamics and on the daily growth rate of Pecten maximus juveniles to further investigate the assumption that this trophic source can affect the biology of this suspension-feeder in a coastal ecosystem: the Bay of Brest. Particular attention is paid to the control by the chemical factors (nitrogen $(\mathrm{N})$, phosphorus (P), silicon (Si)) on the dynamics of primary production and, as a result, on the daily growth rate of Pecten maximus.

\section{MATERIALS AND METHODS}

Study site

The Bay of Brest (France) is a semi-enclosed area and constitutes one of many coastal macrotidal ecosystems that are receiving increasing inputs of nutrients (Le Pape et al., 1996). Over the last twenty years, $\mathrm{N}$ concentrations in rivers have doubled concomitantly with a decrease in the Si-to-N ratio from 2 to 0.33 in coastal seawaters (Le Pape et al., 1996).

Scallops were sampled by dredging in the Roscanvel site (Figure 1). This site (30 m deep) is characterized by heterogeneous sediments and displays one of the most dense scallop populations in the Bay (Grall et al., 1996). Furthermore, it has been used as a reference station for hydrologic parameters since 1977. 


\section{Environmental parameters}

Environmental parameters monitored in 1999, the most intensively surveyed year, included temperature, salinity, pigment concentrations, suspended matter, nutrients and phytoplankton species composition. Measurements were performed daily during algal bloom period vs. weekly during the others periods. Temperature, salinity and fluorescence were recorded using a Sea-bird SBE 19 CTD profiler. Water samples were collected near the bottom and at the surface using 5-l Niskin bottles. For pigment analyses, $1 \mathrm{l}$ of water was filtered through a GF/F filter and stored at $-20^{\circ} \mathrm{C}$ until further analysis. Chlorophyll $a$ and phaeophytin a concentrations were estimated using a calibrated Turner 111 fluorometer, according to Lorenzen (1967). For phytoplankton species determination, $100 \mathrm{ml}$ of the sample was preserved with Lugol's solution and kept in darkness. Silicate, nitrogen (ammonium, nitrate, nitrite) and phosphate concentrations were monitored as potential limiting factors for diatom growth. Ammonium measurements were made according to Koroleff (1969). Phosphate concentrations were measured using the Murphy \& Riley (1962) method. Silicic acid and nitrate + nitrite determination was made using a Technicon autoanalyser II (Treguer \& Le Corre, 1975).

In 1998, environmental monitoring schedule was the same as in 1999, except for suspended solid which was not performed and measurements of phaeophytin $a$ and nutrients which were provided by SOMLIT (Observation station of the littoral; IUEM) at the SainteAnne site (Figure 1). For phytoplankton, data from the Lanveoc site (Figure 1) showed the same trends in relative abundance and species composition as in the bottom sample at Roscanvel. This allowed us to use Lanveoc data (from the REPHY, IFREMER DEL Concarneau) when they were unavailable at Roscanvel. 


\section{Daily growth rings}

Pecten maximus were dredged from February 1998 to August 1999. Sampling was limited to scallops which showed one winter growth mark on the upper valve (class I). Shell growth rate was assessed using image analysis by measuring the distance between daily rings (Chauvaud et al, 1998). After cleaning the external face of the left valve, with $1 \mathrm{~N}$ acetic acid, the distance between rings is measured along the dorso-ventral axis. Ten rings per field were viewed using a video camera (Sony CCD) coupled to a $50 \mathrm{~mm}$ Canon macroscopic lens. Each field was digitised using a Pentium (matrox meteor card, Visilog 5.1 software) to generate a 768*521 pixel image.

\section{RESULTS}

Daily shell growth and environmental parameters in 1998

Daily shell growth of one-year-old juveniles in 1998 presents a classic pattern for the Bay of Brest (See Chauvaud, 1998). After growth began in late March $\left(28^{\text {th }}\right)$, there was a progressive increase in growth rate over the spring, a plateau in May and a slow decrease during autumn. Within this cycle, a strong growth rate decrease was observed for all individuals near the $20^{\text {th }}$ of May (Figure 2A). This event lasted approximately ten days, with daily growth rate dropping from 180 to a low of $80 \mu \mathrm{m}_{\text {day }}{ }^{-1}$ on the second of June. A rapid resumption to a normal maximum growth rate of $220 \mu$ day $^{-1}$ was then observed.

Throughout the study period, temperature, salinity and total suspended solids were not abnormally variable, so those parameters have been ruled out as explanatory factors for the spring growth anomaly. Bottom temperature increased from $8.5^{\circ} \mathrm{C}$ in January to $15.8^{\circ} \mathrm{C}$ in August, and then dropped to $10.5^{\circ} \mathrm{C}$ by the end of December. No major fluctuations of salinity were recorded; the lowest values reached 33.8 PSU. On the other hand, the specific 
composition of phytoplankton, chlorophyll $a$ and phaeophytin $a$ concentrations might have contributed to growth variability. Several chlorophyll $a$ peaks were observed during the year (Figure 2B). Cryptophycae dominated the first bloom, in early May. The second, and largest bloom $\left(8.9 \mu \mathrm{g} \mathrm{l}^{-1}\right)$, was composed primarily of a diatom, Cerataulina pelagica (730 000 cells $\mathrm{l}^{-1}$ ). Chaetoceros curvisetus and C.debile were the dominant species during the remaining blooms. A maximum algal biomass occurred on the $27^{\text {th }}$ May (Figure 2B).

Following peak river flow in mid-April, silicic acid (='silicates') concentration reached a maximum value of $5 \mu \mathrm{M}$ (Figure 2C). Silicates then dropped from late April to late May with a marked acceleration of this trend at the beginning of the Cerataulina pelagica bloom. The collapse of this diatom bloom was concomitant with lowest silicic acid values.

A grazing index, corresponding to the ratio of phaeophytin to total pigments (phaeophytin + chlorophyll $a$ ), showed a decline that clearly appeared the $22^{\text {nd }}$ of May (Figure 2D) during the Cerataulina pelagica efflorescence. The phaeophytin $a$ levels followed the same pattern over time as chlorophyll $a$, except during this bloom .

The maximum near-bottom chlorophyll $a$ concentration during the second spring bloom (Cerataulina pelagica) and the drop in the grazing index were concomitant with the decrease in scallop growth rate. If we superimpose the chlorophyll $a$ profile and P.maximus growth curve, the decreased growth seemed to be initiated when the chlorophyll $a$ concentration reached $5 \mu \mathrm{g} \mathrm{l} \mathrm{l}^{-1}$, and the recovery occurred then when concentrations were below this value (Figure 2E).

Daily shell growth and environmental parameters in 1999

A somewhat similar growth rate pattern was observed in 1999 (Figure 3A); with a rapid increase in early April (daily growth rate increased by a factor 4 between 2 and 15 April), a maximum in June, and a progressive decrease in the autumn. Growth inhibition was 
observed, beginning about the $24^{\text {th }}$ of April. The daily growth increment dropped from 210 to $150 \mu \mathrm{m}$ over a ten-day-period before it rebounded; however, the severe growth inhibition measured in 1998 was not observed during the spring of 1999.

Three chlorophyll $a$ peaks were observed from the start of measurments until 9 June (Figure 3B). All were dominated by diatoms. The first one was composed of Thalassiosira sp. (56\% of total microflora on 2 April), the second peak was dominated by Rhizosolenia delicatula (91\% of total microflora on 30 April) and the third one by Chaetoceros curvisetus

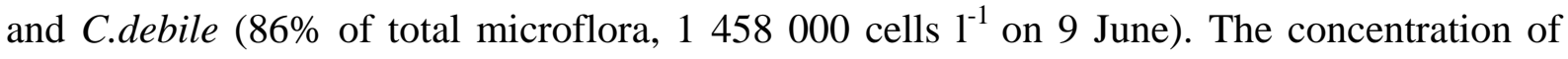
phaeophytin showed the same pattern as the preceding year: the maximum biomass of Rhizosolenia delicatula cells corresponded to the minimum grazing index, suggesting the sinking of undigested cells that became concentrated in near bottom water (Figure 3D).

River flows clearly influenced the chemical environment during the study period. Nitrogen and silicic acid followed similar patterns, with maximum concentrations in late April during the Rhizosolenia delicatula bloom (Figure 3C). High phosphate concentrations were detectable before high freshwater discharges. Those concentrations remained below $0.25 \mu \mathrm{M}$ from early April to late May. The lowest concentrations $(<0.05 \mu \mathrm{M})$ were observed on 24 and 27 April.

Like 1998, the spring growth anomaly corresponded with a diatom bloom. Rhizosolenia delicatula was the dominant species in 1999, but the same chlorophyll $a$ threshold was noted (Figure 3E). The end of the event, characterised by the resurgence of a strong daily growth rate, coincided with the decline of chlorophyll $a$ concentrations below 5 $\mu g l^{-1}$.

Comparison of growth rate patterns over both years

When comparing the two years, striking similarities and differences appeared (Figure 
4) which may be related to inter-annual variations or constancy in environmental factors. The first period observed (April to early May) was characterised by a higher daily growth rate in 1999 than in 1998. The same difference was observed between 1995 and 1994 (Chauvaud et al.,1998). The difference in bottom water temperature was undoubtedly responsible for the growth rate differences in both studies. In 1999, bottom water temperatures were higher than 1998 values from early April until mid-May (Figure 5). The most striking difference between the two years concerned the spring growth slow down, occurring later and more drastically in 1998. For the third period, the progressive autumnal growth decrease occurred approximately at the same time (mid-July). Temperature alone, which continued to increase until August and differed of about $1^{\circ} \mathrm{C}$ between the two years, didn't appear as a convincing causal factor of this trend.

\section{DISCUSSION}

Environmental parameters measured during 1998 and 1999 are close to those generally observed in the Bay of Brest (Quéguiner \& Tréguer, 1984; Del Amo, 1996). However, normal growth (regular bell shaped curve like in 1994, see Chauvaud et al., 1998) was interrupted in spring in each year, albeit to different degrees. The only parameters, showing strong fluctuations during these periods were the species composition of phytoplankton and the chlorophyll $a$ concentration. The hypothesis advanced here is that growth anomalies could be related to phytoplankton blooms. High diatoms densities are the most likely reason for the growth decline as no toxic species were detected during the study period. Two species were involved in growth perturbations: i) Cerataulina pelagica predominated during the 1998 bloom, but is not considered toxic for invertebrates; furthermore, it was present in 1995 without any simultaneous growth slow down, ii) 
Rhizosolenia delicatula, the dominant species of the 1999 bloom, was suspected to inhibit growth of P.maximus juveniles in 1995 (Chauvaud et al., 1998). These two diatom species are in a similar size range (diameter of $20-50 \mu \mathrm{m}$ ), of elongated shape without spines, and exist in chains or as separate cells. Their morphological characteristics do not allow us to determine whether growth perturbations are species specific. Another likely correlate is total phytoplankton biomass, although species composition cannot be ruled out.

In 1998 and 1999, a decrease in the growth rate, observed as an extra major ring on juvenile shells, was initiated when bottom-water algal concentration exceeded $5 \mu \mathrm{g} \mathrm{l}^{-1}$. The growth resumption appeared when the concentration was below this threshold. However, depending on the year, the impact on growth was not of the same amplitude. Although species characteristics do not allow us to establish their contribution in different level of growth perturbation, several hypotheses can be offered to explain these observations.

Theoretically, normal shell deposition can take place only when the valves are open and the mantle well extended along the margins (Pannela \& MacClintock, 1968). A growth slow-down might result from a bivalve's incapacity to maintain its valves open because of the high algal biomass. Indeed, Malouf \& Bricelj (1989) have previously showed an alteration in filtration rates of the hard clam, Mercenaria mercenaria, by a high algal density. Further, Chauvaud et al., (1998) pointed out that clogged gills stopped scallops from ingesting food properly, which had a negative impact on growth. Events of 1998 and 1999 appear to confirm this hypothesis. Thus, growth would be limited by ingestion capacity of P.maximus. However, Lewis \& Cerrato (1997) showed that shell growth of the soft shell clam, Mya arenaria, is not a direct response to nutritive activity, but could be positively correlated with oxygen consumption. According to their findings, the growth slow-down observed in juvenile scallops could correspond to a perturbation of respiratory activity more than of food intake. Respiration might be altered by gill clogging or by oxygen depletion at the water-sediment 
interface. Indeed, the intensification of bacterial activity and degradation of organic matter, that follows the sinking of a plankton bloom, could produce hypoxia at the water-sediment interface. Oxygen measurement is not available for the micro-layer where scallops live. It would be interesting to obtain oxygen measurements in this layer, but it would be surprising if oxygen depletion could occur in the well mixed Roscanvel site (Salomon \& Breton, 1996). Nevertheless, at a P.maximus scale, a micro-depletion could have serious repercussions on growth. Although the exact mechanism remains unknown, this study permits the generalisation that P.maximus daily growth perturbation were strongly associated with high algal biomass of two different diatom species.

If we try to understand why such food is so abundant on the bottom layer, several explanations are of interest. First, the high concentrations might be the result of tidal current dynamics in the Bay. But present knowledge of instantaneous and residual currents do not allow us to determine particles trajectories at scales as small as several days (Le Pape, 1996; Salomon \& Breton, 1996). Such an hypothesis can't be accepted or rejected, although it is improbable that the high concentrations come from outside of the Bay (Salomon, pers. comm.).

Chauvaud et al.(1998) hypothesised that massive sedimentation of diatom blooms leads to high chlorophyll $a$ concentrations in bottom water, affecting the metabolism and consequently the shell growth of Pecten maximus. And according to Ragueneau et al.(1996), if dissolved silicic acid $\left[\mathrm{Si}(\mathrm{OH})_{4}\right]$ became limiting at the surface, cells could form aggregates surrounded by a gelatinous matrix. Numerous previous studies have documented the capacity of diatoms to acquire new proprieties: e.g. flocculation of diatom blooms, formation of diatom aggregates (Krank \& Miligan, 1998; Alldredge \& Gotschalk, 1989; Riesbell, 1991).

Further, Bienfang et al. (1982) demonstrated using in vitro studies that sinking of nutrientdepleted diatom populations was related to the kind of nutrient available and that it varied 
among species. In particular, Si-depletion accelerates most diatoms sinking, as diatoms have an absolute Si requirement for growth (Smetacek, 1985). The depletion of $\left[\mathrm{Si}(\mathrm{OH})_{4}\right]$ has been shown to cause spring bloom collapses in coastal waters (Conley \& Malone, 1992; Conley et al., 1993). Although mucous secretion increases in nutrient-depleted diatom populations (Degens \& Ittekot, 1984), the dynamics of aggregation is poorly understood (Alldredge \& Gotschalk, 1989; Alldredge et al, 1995). Observation of nutrient concentrations in parallel to diatom bloom dynamics in this study strongly suggests that diatoms sink due to nutrient limitation. This limitation can be observed first with Redfield ratios (Del Amo et al., 1997), which give estimates of relative nutrient requirements by diatoms (SI:N:P = 16:16:1). In 1998, only silicic acid and dissolved inorganic nitrogen measurements (nitrate + nitrite + ammonium) are available. The low Si:N ratios ( $<1$, Figure 6A) from late March to late July suggests that Si was potentially the most limiting nutrient during this period, but we cannot rule out the possibility of a phosphate limitation, as no data on this element are available. Real limitation depends then on the algal species composition and on specific kinetic curves. In situ concentrations must be compared to half-saturation constants for nutrient uptake (Km). If concentrations are below the $\mathrm{Km}$, uptake is reduced and algal growth is potentially limited. According to Del Amo et al. (1997), Km values of 0.2, 2.0 and $2.0 \mu \mathrm{M}$ for phosphate, silicic acid and nitrogen, respectively, are considered reasonable for the Bay of Brest. During the spring bloom, silicate concentration remained below the $\mathrm{Km}(2 \mu \mathrm{M})$ and even until July (0.6$0.8 \mu \mathrm{M}$ during the bloom). So even if $\mathrm{Si}$ is not the primary limiting nutrient (as $\mathrm{P}$ concentrations are not available), Si limitation does occur. Furthermore, Del Amo et al. (1997) also suggested that Si limitation of siliceous-phytoplankton-dominated spring blooms represented the response of the Bay of Brest ecosystem to high-nitrate-loaded fresh-water inputs.

With respect to the Si:N ratio, the 1999 bloom periods would be potentially Si limited 
(Si:N < $1 \mu \mathrm{M}$ ) as in 1998 (Figure 6B). However, ambient Si concentrations remained above 2 $\mu \mathrm{M}$ during all the blooms and high Si:P ratios (largely $>16$, Figure $6 \mathrm{C}$ ) suggests that $\mathrm{P}$ limitation was more important than $\mathrm{Si}$ limitation. Comparison of mean $\mathrm{Km}$ values for phosphate uptake confirm that the major bloom was effectively P limited (ambient values of $0.05 \pm 0.02 \mu \mathrm{M}$ were less than the $0.2 \mu \mathrm{M} \mathrm{Km}$ value) in 1999. On the other hand, in 1998, silicic acid, rather than phosphate, is inferred to have been a limiting factor responsible for the collapse of the spring bloom.

According to Bienfang et al (1982), sinking velocity is minor when phosphate is limiting in culture. This may explain why the phenomenon appeared to be more pronounced in 1998 as phosphate depletion in 1999 may not have been sufficient enough to cause a sinking episode. This is consistent, too, with the hypothesis of an aggregation of particles due to Si depletion. Clogging of gills and consequent growth perturbation would be greater with aggregated cells. Thus, the difference in sinking dynamics could explain why the incident was observed in 1999 but with lower amplitude. Phytoplankton concentrations inhibited growth in 1999, but not as much as overall events in 1998.

Further support for the collapse of the phytoplankton blooms due to nutrient limitation is seen in the grazing index. Relatively intact diatoms that reach the deep-sea floor without being ingested by zooplankton (Smetacek, 1985) often dominate this rapidly sinking phytoplankton mass. Data on phaeophytin $a$ and the grazing index for the two years confirm this hypothesis. Indeed, it seems that a large amount of chlorophyll $a$ arrived at the sea-floor without being damaged, as evidenced by low values of the grazing index. This could reinforce the hypothesis of sedimentation. In any case, the low grazing index confirms that diatom blooms give rise to perturbations, at a large scale, of phytoplankton grazers in the Bay of Brest. 


\section{CONCLUSION}

This study, conducted in the Bay of Brest on the effects of environmental factors on the daily growth rate of Pecten maximus juveniles has confirmed several hypotheses. High levels of chlorophyll $a$, as in 1995 (Chauvaud et al., 1998), are not necessarily correlated with high growth rates. In 1998 and 1999, peaks were even associated with a slowing of growth. Large bottom concentrations of chlorophyll $a$, following diatom blooms, could have a negative effect on the ingestion or respiration of P.maximus juveniles, either by gill clogging or by oxygen depletion at the water-sediment interface associated with the degradation of organic matter. Sedimentation mechanisms in relation to the dynamics of the nutrients seem of interest for a better understanding of diatom mass sinking. A clear resolution of this question will require experiments designed to address Si or P-limited growth directly in natural diatom assemblages. Furthermore, an experimental protocol of monitoring scallop respiration when algal concentration is high, coupled with in situ measurement of oxygen and food intake during a bloom, would be necessary to confirm or reject these hypotheses.

The fact that microgrowth patterns accurately reflect environmental changes has many applications to ecological and paleoecological problems. This would include for example, identification or reconstitution of stress gradients or paleolatitudes, by comparison of growth patterns between specimens collected from different biotopes or in fossil molluscs. Further work on bottom-water molluscs is required to define the temporal and spatial ranges of these growth anomalies.

\section{Acknowledgements}

We would like to thank Alain Le Mercier for image analysis, Servane Fixot for data treatment and helpful comments, Robert Marc for in situ measurements (sampling at sea) and Suzanne Ford for English corrections of the manuscript. The authors are also particularly grateful to Edouard Kraffe de 
Laubarède and Annick Masson for nutrient analysis, and to the staff of the SOMLIT network, Stéphane Blain and Jacques Guillou.

\section{REFERENCES}

Alldredge, A.L.\& Gotschalk, C.C., 1989. Direct observations of the mass flocculation of diatom blooms: characteristics, settling velocities and formation of diatom aggregates. Deep Sea Research, 36, 159-171.

Alldredge, A.L., Gotschalk, C.C., Passow, U. \& Riesbell, U., 1995. Mass aggregation of diatom blooms: Insights from a mesocosm study. Deep Sea Research, 42, 9-27.

Bienfang, P.K., Harrison, P.J.\& Quarmby, L.M., 1982. Sinking rates response to depletion of nitrate, phosphate and silicate in four marine diatoms. Marine Biology, 67, 295-302.

Broom, M.J.\& Mason, J., 1978. Growth and spawning in the Pectinid Chlamys opercularis in relation to temperature and phytoplankton concentration. Marine Biology, 92, 277285.

Chauvaud, L., 1998. La coquille Saint-Jacques en rade de Brest: un modèle biologique d’étude des réponses de la faune benthique aux fluctuations de l'environnement. Thèse de doctorat, Université de Bretagne Occidentale, Brest-France, 266pp.

Chauvaud, L., Thouzeau, G. \& Paulet, Y.M., 1998. Effects of environmental factors on the daily growth rate. Journal of Experimental Marine Biology and Ecology, 227, 83-111.

Conley, D.J.\& Malone, T.C., 1992. Annual cycle of dissolved silicate in Chesapeake Bay: implications for the production and fate of phytoplankton biomass. Marine Ecology Progress Series, 81, 121-128.

Conley, D.J., Schelske, C.L.\& Stoermer, E.F., 1993. Modification of the biogeochemical cycle of silica with eutrophication. Marine Ecology Progress Series, 101, 179-192. 
Degens, E.T.\& Ittekot, V., 1984. A new look at clay-organic interactions. Mitteilung des Geologischen und Paläontologischen Instituts der Universitat Hamburg , 56, 229-248.

Del Amo, Y., 1996. Dynamique et structure des communautés phytoplanctoniques en écosystème côtier perturbé; cinétique de l’incorporation de silicium par les diatomés. PhD dissertation, Université de Bretagne Occidentale, Brest.

Del Amo, Y. Queguiner, B., Treguer, P., Breton, H.\& Lampert, L., 1997. Impacts of highnitrate freshwater inputs on macrotidal ecosystems. I. Seasonal evolution of nutrient limitation for the diatom-dominated phytoplankton of the Bay of Brest (France) Marine Ecology Progress Series, 161, 225-237.

Grall, J., Chauvaud, L., Thouzeau, G., Fifas, S., Glemarec, M. \& Paulet, Y.M., 1996. Distribution de Pecten maximus (L.) et de ses principaux compétiteurs et prédateurs potentiels en rade de Brest. Compte Rendu de l'Académie des Sciences Paris, 319, 931-937.

Koroleff, F.,1969. Direct determination of ammonia in natural waters as indophenol blue. International Council for the Exploration of the Sea, C.M., 9, 19-22.

Krank, K.\& Milligan, D., 1988. Macroflocs from diatoms: In-situ photography of particles in Bedford Bassin, Nova Scotia. Marine Ecology Progress Series, 44, 183-189.

Le Pape, O., 1996. Modélisation des cycles biogéochimiques des éléments limitant la production phytoplanctonique en rade de Brest. Thèse de doctorat, Ecole Nationale Supérieure d’Agronomie de Rennes, Rennes, 195pp.

Le Pape, O., Del Amo, Y., Menesguen, A., Aminot, A., Queguiner, B.\& Treguer, P., 1996. Resistance of a costal ecosystem to increasing eutrophic conditions : the Bay of Brest (France), a semi-enclosed zone of Western Europe. Continental Shelf Research, 16, 1885-1907.

Lewis, D.E.\& Cerrato, R.M., 1997. Growth uncoupling and the relationship between shell 
growth and metabolism in the soft shell clam Mya arenaria. Marine Ecology Progress Series, 158, 177-189.

Lorenzen, C., 1967. Determination of chlorophyll and phaeophytin: spectrophometric equation. Limnology and Oceanography, 12, 343-346.

Lutz, R.A.\& Rhoads, D.C., 1980., Growth patterns within the molluscan shell: an overview: in Skeletal Growth of Aquatic Organisms: Biological records of Environmental changes (ed. Rhoads, D.C., and Lutz, R.A.), pp. 203-254. New York: Plenum Press.

MacDonald, B.A.\&Thompson, R.J., 1985. Influence of temperature and food availability on the ecological energetics of the giant scallop Placopecten magellanicus. I. Growth rates of shell and somatic tissue. Marine Ecology Progress Series, 25, 279-294.

Malouf, R.E.\& Bricelj, V.M., 1989. Comparative biology of clams : environmental tolerance, feeding and growth. 2 In Clam Mariculture in North America, Chapter 2 (ed. J.Manzi et M.Castagna), 23-73, New-York : Elsevier.

Murphy, J.\& Riley, J.P., 1962. A modified single solution method for the determination of phosphate in Natural waters. Analytica Chimica Acta, 27, 31-36.

Pannela, G.\& MacClintock, C.,1968. Biological and environemental rhythms reflected in molluscan shell growth. Journal of Paleontology Memoir, 42 (5), 64-80.

Queguiner, B.\& Treguer, P., 1984. Studies on the phytoplankton in the Bay of Brest (Western Europe). Seasonal variations in composition, biomass and production in relation to hydrological and chemical features (1981-1982). Botanica Marina, 27, 449-459.

Ragueneau, O., Queguiner, B.\& Treguer, P., 1996. Contrast in Biological Responses to Tidally-induced Vertical Mixing for Two Macrotidal Ecosystems of Western Europe. Estuarine, Coastal and Shelf Science, 42, 645-665.

Riebessel, U., 1991. Particle aggregation during a diatom bloom. II. Biological aspects. Marine Ecology Progress Series, 69, 281-291. 
Salomon, J.C. \& Breton, M., IFREMER 1996. Les principales caractéristiques du bassin versant de la rade de Brest. I.1. Le milieu physique, pp 42-46 in Contrat de Baie. La rade de Brest et son bassin versant. Etat des lieux et des milieux. Avril 1997.

Smetacek, V., 1985. Role of sinking in diatom life-history cycles: Ecological, evolutionnary and geological significance. Marine Biology, 84, 239-251.

Treguer, P.\& Le Corre, P., 1975. Manuel d'analyse des sels nutritifs dans l'eau de mer. Utilisation de l'Auto-Analyseur II: Technicon. Laboratoire d'Océanographie Chimique, Université de Bretagne Occidentale, Brest, 2ème édition, 110pp. 
Figure 1. Map of the Bay of Brest (France) showing the main sampling sites: Roscanvel (RO), SainteAnne (SA) and Lanvéoc (LA).

Figure 2. 1998 temporal variations between March and September (A) mean daily shell growth rate of juvenile Pecten maximus at Roscanvel $\left(\mu \mathrm{m}^{\text {day }^{-1}}\right.$; verticals bars $=95 \%$ C.L.); (B) bottom water chlorophyll $a$ concentrations ( $\mu \mathrm{g} \mathrm{l}^{-1}$, Roscanvel) and phytoplankton species composition (Lanvéoc); (C) averaged daily flow rate $\left(\mathrm{m}^{3} \mathrm{~s}^{-1} / 20\right)$ and silicic acid concentrations (Sainte-Anne, $\left.\mu \mathrm{M}\right)$; (D) grazing index (Sainte-Anne, phaeophytin / (phaeophytin + chlorophyll $a$ ); (E) daily growth rate compared to bottom chlorophyll $a$ concentrations.

Figure 3. 1999 temporal variations between March and September in the Roscanvel site (A) mean daily shell growth rate of juvenile Pecten maximus at Roscanvel $\left(\mu\right.$ day $^{-1}$; verticals bars $=95 \%$ C.L.); (B) bottom water chlorophyll $a$ concentrations $\left(\mu \mathrm{g} \mathrm{l}^{-1}\right)$ and phytoplankton species composition ; (C) averaged daily flow rate $\left(\mathrm{m}^{3} \mathrm{~s}^{-1} / 20\right)$ and silicic acid, nitrogen (nitrate + nitrite + ammonium) and phosphate concentrations ( $\mu \mathrm{M})$; (D) grazing index (phaeophytin / (phaeophytin + chlorophyll $a$ ); (E) daily growth rate compared to bottom chlorophyll $a$ concentrations.

Figure 4. Comparison of mean daily shell growth rates of Pecten maximus juveniles (Class I) in 1998 and 1999.

Figure 5. Temporal variation of bottom water temperatures from March to September in 1998 and 1999.

Figure 6. (A) Molar ratios of Si:N between March and September 1998. (B) Molar ratios of Si:N from March to June 1999. (C) Molar ratios of Si:P from March to June 1999. The Si:N = 1, Si:P = 16 lines correspond to Redfield theoretical values and determine the potential limiting nutrients. 


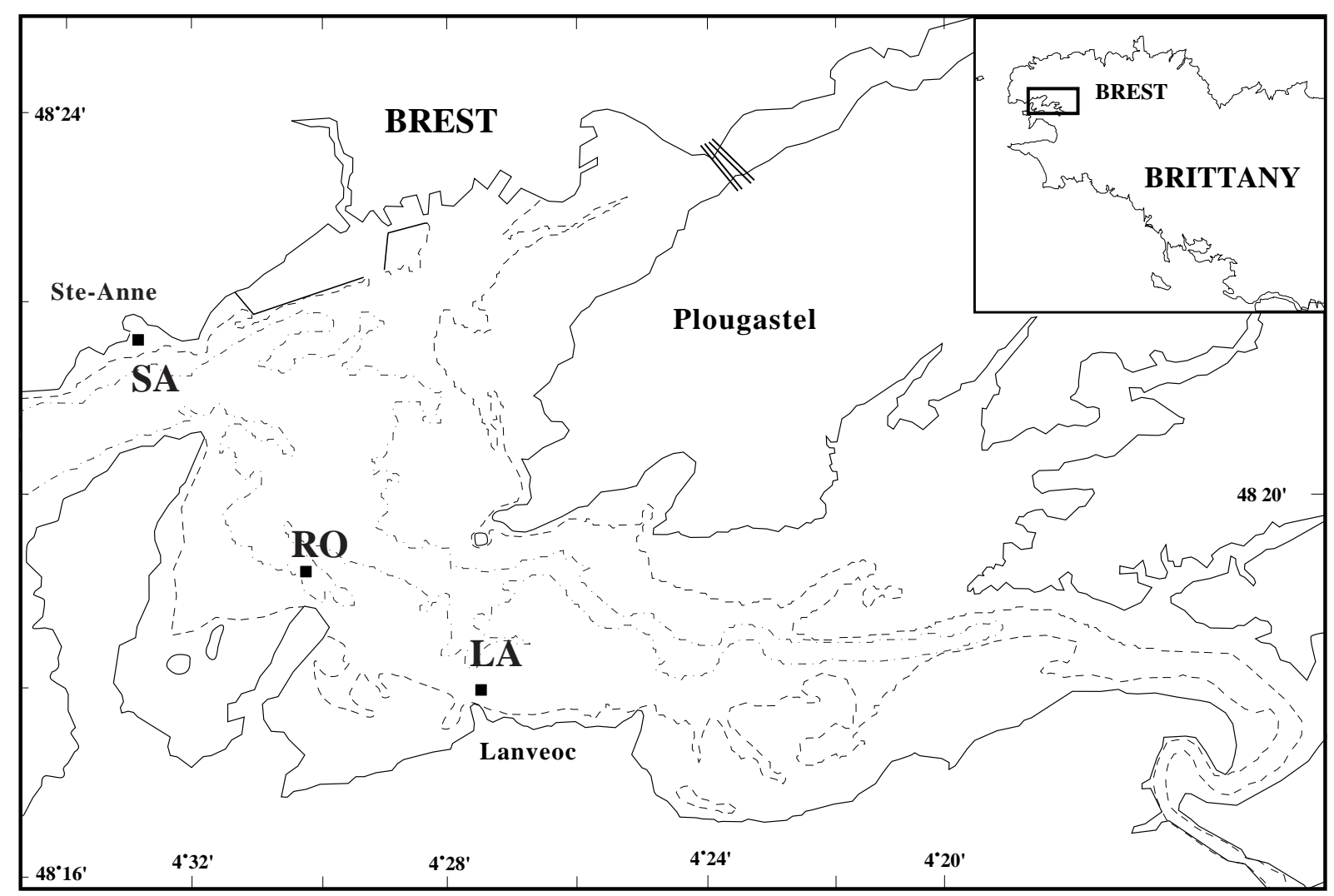


A

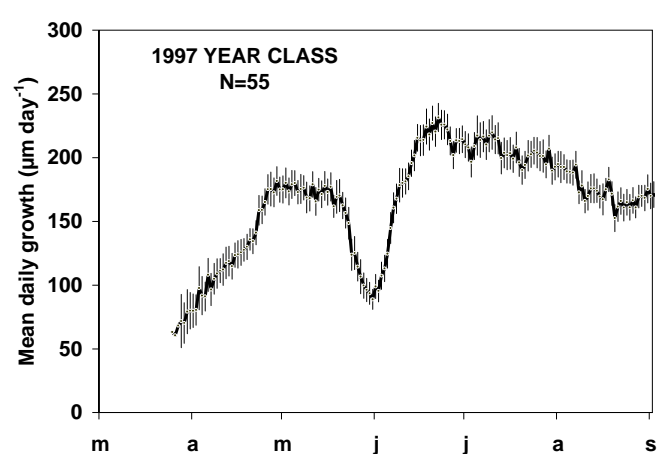

C

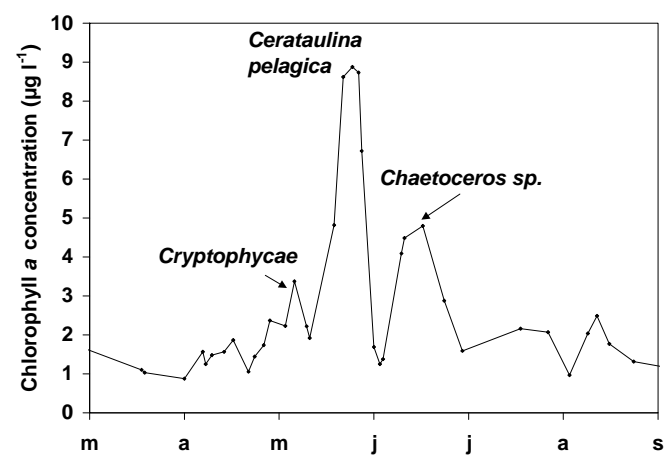

\section{E}

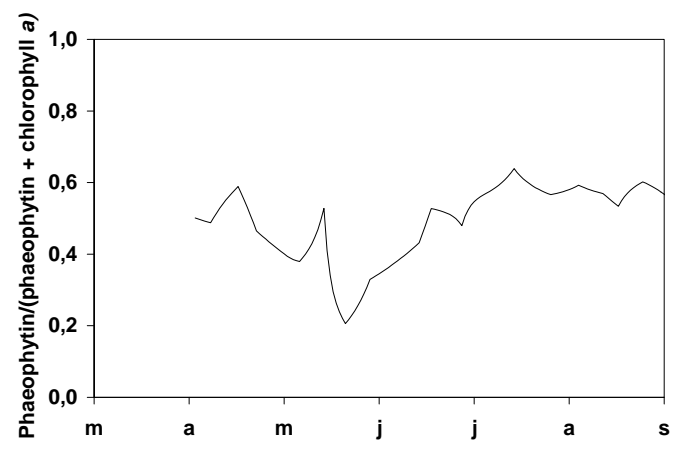

B

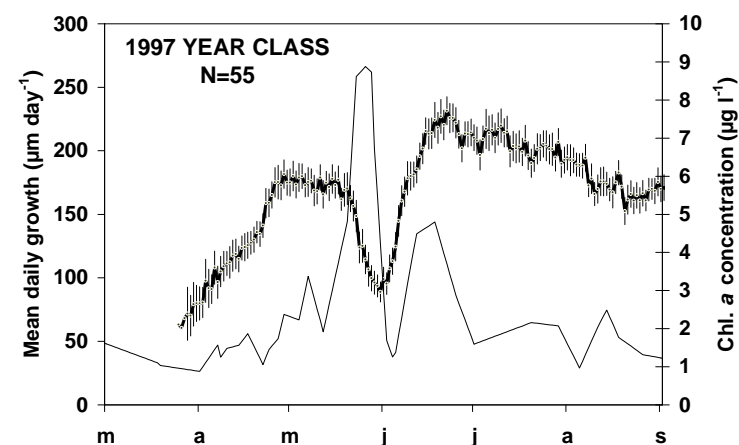

D

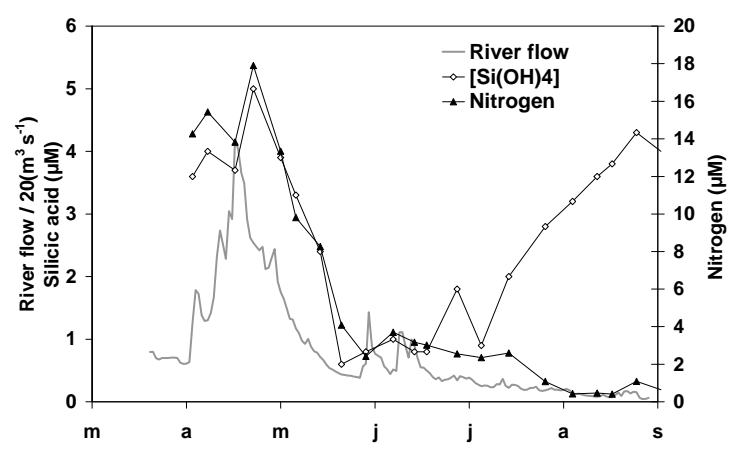


A

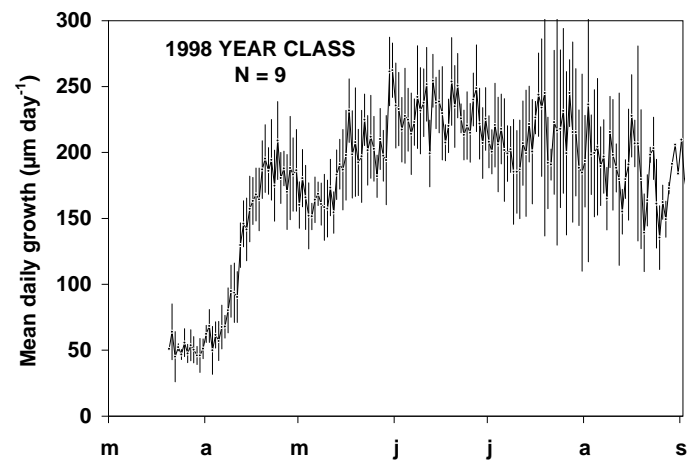

B

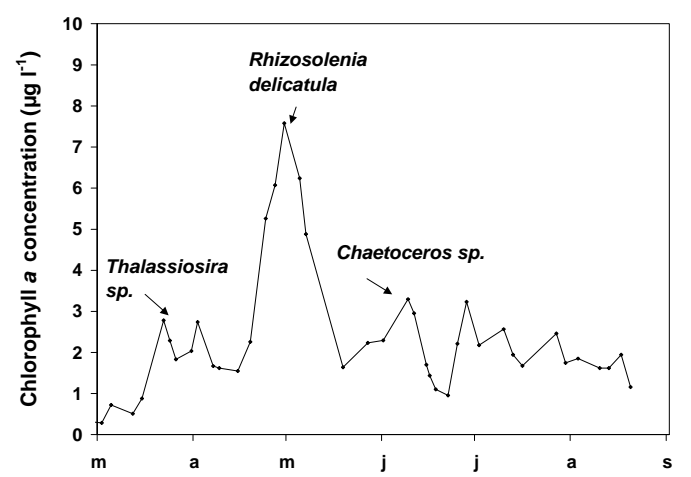

C

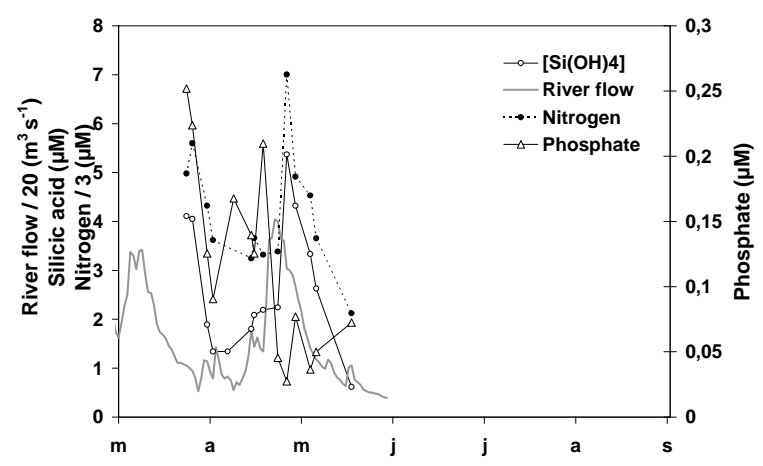

D

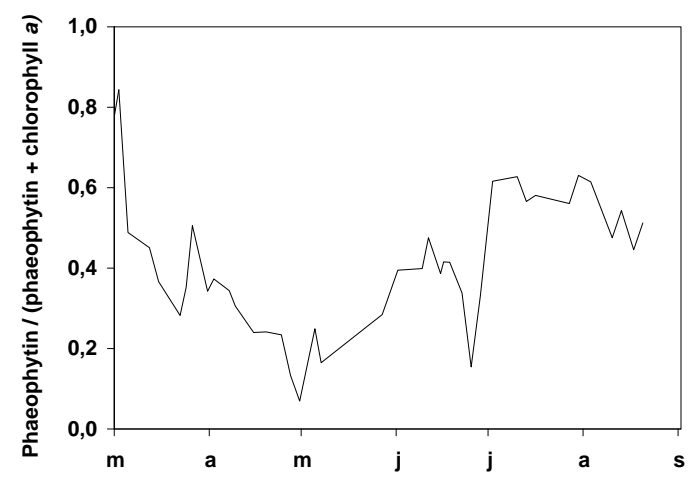

E

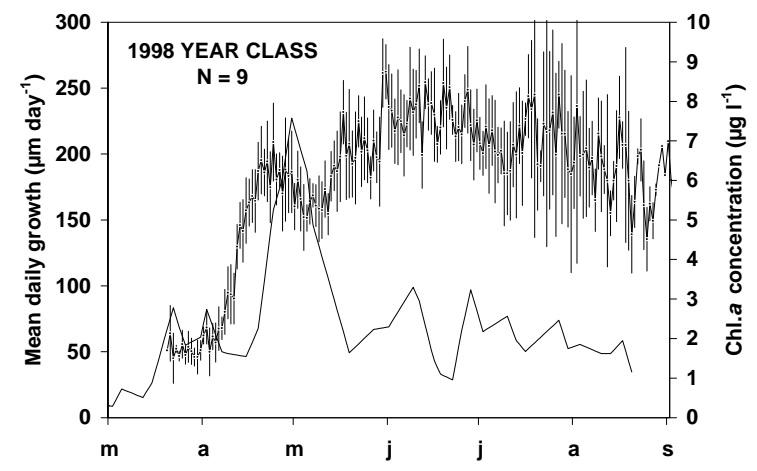



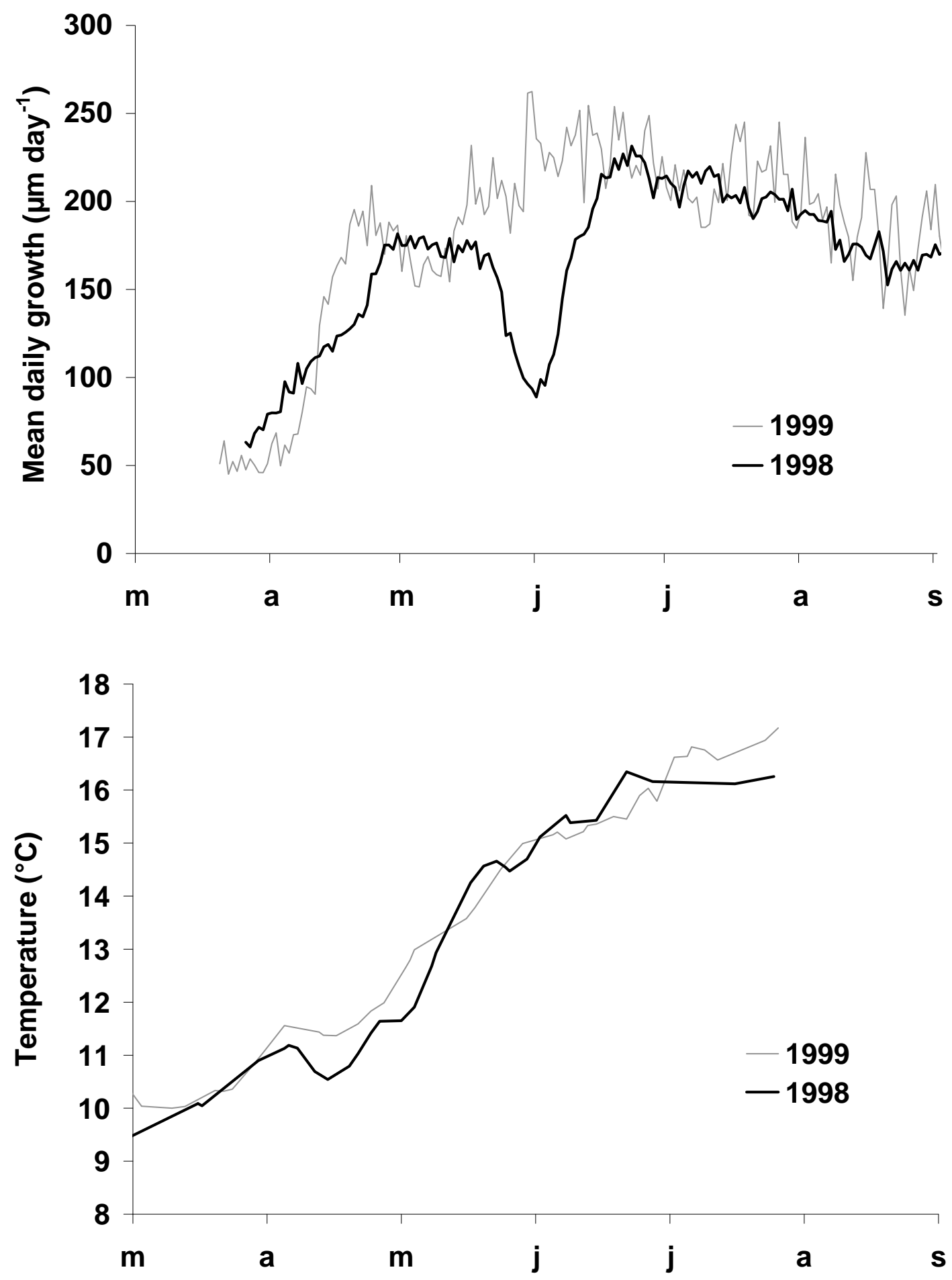

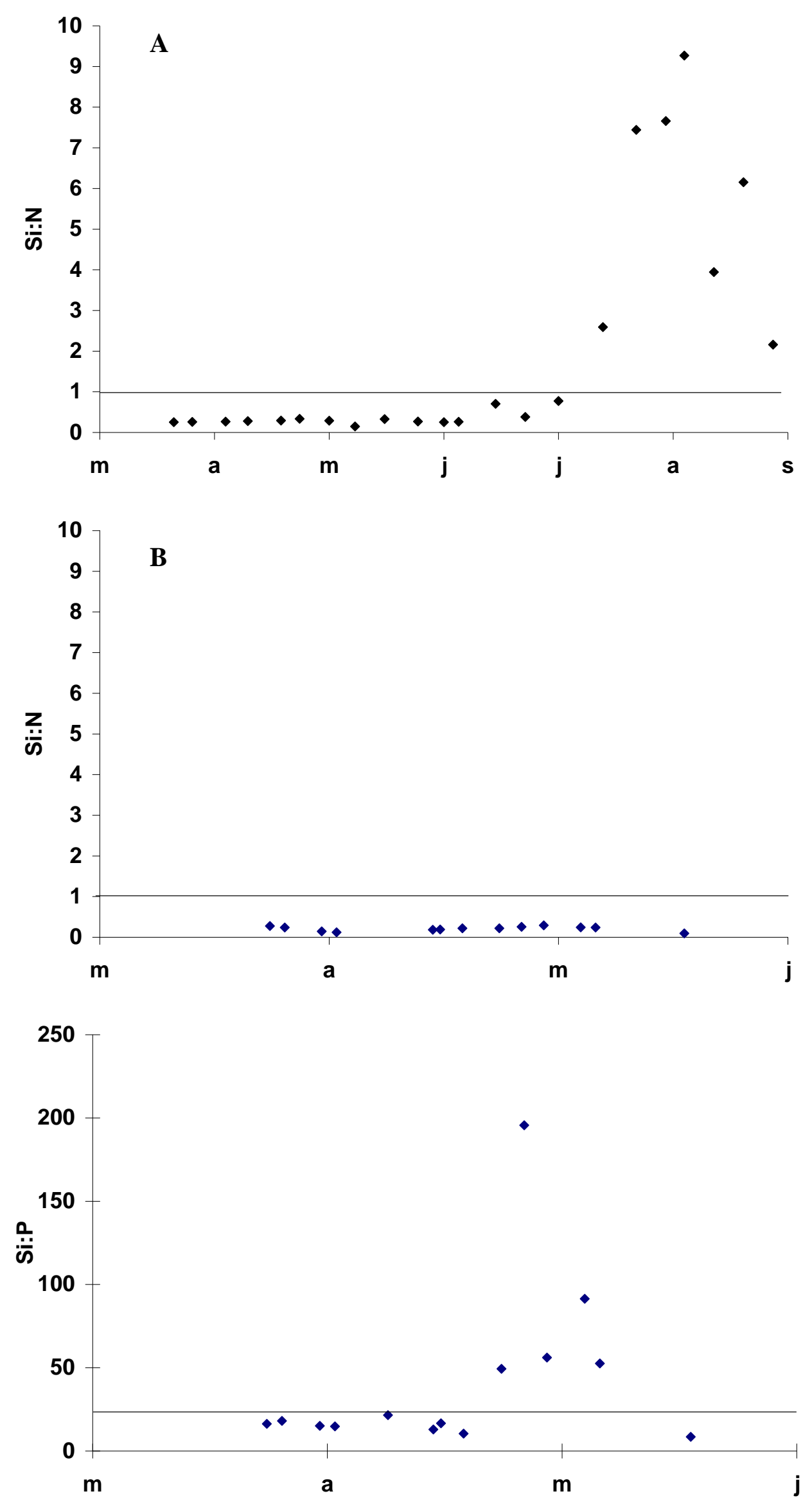
